\title{
ANALYSIS AND COMPARISON OF THE FREQUENCY OF PATHOLOGICAL CONDITIONS AND LESIONS IN SLAUGHTERED ANIMALS IN POLAND IN 2009 AND 2017
}

\author{
Department of Animal Reproduction and Hygiene, Siedlce University of Natural Sciences \\ and Humanities, Poland
}

\begin{abstract}
The aim of the study was to analyze and compare the frequency of symptoms and pathological conditions in slaughtered animals in 2009 and 2017, and to determine the reasons behind their presence. The results of official post-mortem assessment of cattle, pigs and sheep carried out by the Veterinary Inspection were analyzed. When analyzing the causes of lesions or pathological symptoms and unfitness for consumption, the following conditions have been included: tuberculosis, actinomycosis, as well as quality deviations: emaciation and watery muscles, icterus, organoleptic changes, incomplete loss of blood, natural death, slaughter in agony, foci of pus, contamination and congestions, as well as other changes and parasitic invasions: cysticercosis, echinococcosis, fasciolosis and trichinellosis. It was found that the number of slaughtered animals exhibiting health condition deviations or symptoms and pathological changes remains at a high level in Poland, and it even demonstrates a slight increase in case of cattle. A large number of contamination and congestions indicates low attention to the conditions of ante-mortem trading in terms of slaughtered animals, as well as to hygiene and conditions for slaughtering, cutting and carcass processing. Quality deviations in the form of emaciation and watery muscles or incomplete loss of blood in slaughtered animals indicate mistakes made during breeding or when transporting the slaughtered animals. Having considered the foregoing, there may be justified concerns about the appropriate level of animal welfare. Parasitic diseases, especially fasciolosis in cattle and sheep, and echinococcosis in pigs in some areas require more effective actions to reduce them. On the other hand, a very small number of cases of trichinellosis in pig meat can be considered satisfactory.
\end{abstract}

Key words: slaughtered animals, post-mortem inspection, lesions.

\section{INTRODUCTION}

The meat industry is the largest part of the Polish food industry, and producers of meat and meat-derived products have a significant position in the domestic trade trading (Drożdż 2018). In 2017, the consumption of meat, offal and meat products in Poland amounted to $74.6 \mathrm{~kg}$ per capita. The consumption of pork was $38.2 \mathrm{~kg}$, the consumption of poultry $27.6 \mathrm{~kg}$ and the consumption of beef remained at a low level of $3.2 \mathrm{~kg}$ per capita per annum (Świetlik 2019). The consumption of lamb meat was less than $1 \mathrm{~kg}$ per capita (Niżnikowski et al. 2017). In addition to the desired sensory and nutritional qualities, any food must meet consumers' expectations as regards safety. The safety of raw materials for the production of meat products

Corresponding author: Krzysztof Górski, Department of Animal Reproduction and Hygiene, Siedlce University of Natural Sciences and Humanities, Bolesława Prusa 14, 08-110 Siedlce, Poland, e-mail: krzysztof.gorski@uph.edu.pl, ORCID: 0000-0002-9165-504X 
depends on the health of slaughter livestock (Januškevičiené et al. 2010). A measurable indicator of the health and hygienic condition of slaughter animals is the frequency of changes and disease conditions, as well as quality deviations found during the sanitary and veterinary examination of slaughter animals before and after slaughtering (Sánchez et al. 2018). The quality of carcasses and meat depends on the technology of rearing and on the conditions of transport and ante-mortem trading of animals. The cause of the disease is usually dietary mistakes and improper hygienic conditions of animals and animal enclosures (Kondracki et al. 1996; Butler 2000). Disease-related lesions and damage to animal carcasses also occur when handling animals before slaughter. Because of that, increasingly more attention is being paid to optimizing the animal treatment during ante-mortem trading (Wajda and Burczyk 2017).

Changes or symptoms observed before and after animal slaughter shall provide information on the health status and animal welfare. Therefore, research in this area should be carried out systematically (Kozák et al. 2002; Nielsen 2011). Examination of animals for slaughter and meat constitutes a tool to reduce or even exclude risks to consumer safety and health. The problem is infections of animals that do not generate recognizable clinical signs during breeding or fattening. Over the last years, a number of reports have been published in Poland concerning the assessment of slaughter animals, as well as the meat of poultry and free-living animals in Poland (Libelt 2001; Radkowski et al. 2010; Szkucik et al. 2012; Szkucik et al. 2014; Lis and Górski 2017a, b). The results of these tests show a significant number of animals for slaughter, especially cattle and pigs with symptoms or lesions.

The aim of this study is to analyze and compare the frequency of symptoms and lesions in slaughter animals in Poland in 2009 and 2017 and the causes of their presence.

\section{MATERIAL AND METHODS}

The data from the sanitary and veterinary examination was analyzed and taken from the annual reports drawn up by the Chief Veterinary Inspectorate (RRW-6) in 2009 and 2017. Post-mortem inspection included visual inspection of carcasses and organs. Pathological lesions were identified and registered through palpation and incision of suspicious organs. An analysis of the causes of disease changes and inability to eat carcasses of slaughter animals was also carried out. Assessing the causes of disease changes and unfitness for consumption included diseases such as: tuberculosis, actinomycosis and sepsis, as well as qualitative deviations: emaciation and watery muscles, icterus, organoleptic changes, incomplete blood loss, natural death, slaughter in agony, foci of pus, contamination, congestion and other lesions and parasitic invasions: cysticercosis, echinococcosis, fasciolosis and trichinellosis. The analysis of the results took into account the number of examined animals, the number of carcasses found to be diseased and the number of carcasses declared unfit for consumption. The frequency of occurrence for disease-related lesions and diseases was calculated by dividing their number by the number of examined animals of a given species.

The collected specimens were compiled according to the frequency of pathological changes found in the sanitary and veterinary examination of cattle, pigs and sheep in particular voivodeships in Poland, and then their percentage structure was determined. The analysis of changes in the frequency of occurrence for pathological conditions and pathological changes in slaughter animals in 2009 and 2017 was also performed. Data for 2009 was taken from previous studies (Lis and Górski 2011b; Lis and Iwanina 2011; Lis and Górski 2012). 


\section{RESULTS AND DISCUSSION}

The data allowing to compare frequency of lesionns and or pathological symptoms in slaughter animals in Poland in 2009 and 2017 is presented in Table 1.

Table 1. Comparison of pathological condition and lesion frequency in animals slaughtered in Poland in 2009 and 2017

\begin{tabular}{lrrrrrr}
\hline \multirow{2}{*}{ Species } & \multicolumn{2}{c}{$\begin{array}{c}\text { Number of examined } \\
\text { animals }\end{array}$} & \multicolumn{2}{c}{$\begin{array}{c}\text { Number and percentage of animals with } \\
\text { lesions or pathological symptoms }\end{array}$} & \multicolumn{2}{c}{$\begin{array}{c}\text { Number and percentage of } \\
\text { carcasses unfit for consumption }\end{array}$} \\
\cline { 2 - 8 } & \multicolumn{1}{c}{2009} & \multicolumn{1}{c}{2017} & 2009 & 2017 & \multicolumn{1}{c}{2009} & 2017 \\
\hline Cattle & 1594697 & 1991412 & $312147(19.57)$ & $411886(20.68)$ & $4330(0.27)$ & $4513(0.23)$ \\
Pigs & 17804557 & 22316310 & $6731752(37.81)$ & $7912069(35.45)$ & $35162(0.20)$ & $25199(0.11)$ \\
Sheep & 23593 & 43283 & $8576(36.35)$ & $3202(7.40)$ & $39(0.16)$ & $56(0.13)$ \\
Total & 19422847 & 24351005 & $7052475(36.31)$ & $8327157(34.20)$ & $39531(0.20)$ & $29768(0.12)$ \\
\hline
\end{tabular}

According to this data, over 24.3 million animals were slaughtered under veterinary supervision in 2017, including over 1.9 million cattle, over 22.3 million pigs and over 43.28 thousand sheep. In comparison to 2009 , the number of examined slaughter animals increased by nearly 5 million, i.e. by about $20 \%$.

Table 1 also shows that during ante- and post-mortem examination, diseases or lesions were found in more than 8.32 million, i.e. $34.20 \%$ of the examined slaughter animals. The highest percentage of animals showing disease changes was found in pigs (over $35 \%$ ). In case of cattle and sheep, the percentage of animals showing lesions was much lower and did not exceed $21 \%$. When comparing this data with the results of the 2009 slaughter animal study, it should be concluded that the percentage of pigs and sheep showing lesions has decreased. In case of pigs, the proportion of animals with disease lesions decreased by $2.35 \%$. In case of sheep, the decrease in the percentage of animals with disease changes was much greater and amounted to $28.95 \%$. On the other hand, in terms of cattle, the percentage of animals with disease changes increased by about $1 \%$. The increasing incidence of disease lesions in cattle is a cause for concern. More than 29,76 thousand $(0.12 \%)$ of the tested carcasses were declared unfit for consumption. The percentage of carcasses unfit for consumption ranged from $0.11 \%$ for pigs to $0.23 \%$ for cattle and in 2017 it was slightly lower than in 2009 .

Table 2 presents a comparison of data showing the frequency of disease changes in particular species of animals for slaughter in 2009 and 2017, according to the type of changes.

This data shows that, by health and veterinary examination in both bovine, porcine and ovine animals, cases of tuberculosis, actinomycosis. sepsis and icterus have been identified, as well as cases of incomplete blood loss, natural death and slaughter in agony. Foci of pus and contaminants or congestion, echinococcosis and other parasites have also been found in the carcases of all these species. Cases of cysticercosis have been reported in cattle and pigs, cases of erysipelas in pigs and, cases of liver fluke in cattle and sheep.

Table 2 shows that the most common pathological changes are foci of pus, congestion and contaminants. This applies especially to pigs in which such changes were found in more than $28 \%$ of the examined carcasses, while the percentage of all observed disease changes in this species was only about $7 \%$ higher. In the carcasses of cattle and sheep, foci of pus, congestion and contamination also accounted for the major part of all observed lesions. However, they occurred much less frequently than in pigs and applied to $10.2 \%$ of the inspected cattle 
carcasses and $2.86 \%$ of the examined sheep carcasses. Changes as such may be due to inappropriate handling of slaughtered animals during transport, as well as before and during slaughter itself. A large number of impurities and blood congestions may indicate poor hygienic quality during the cutting and processing of carcasses.

Table 2. Frequency of disease lesions in 2009 and 2017 by lesion type

\begin{tabular}{|c|c|c|c|c|c|c|}
\hline \multirow{3}{*}{ Type of lesions } & \multicolumn{2}{|c|}{ Cattle } & \multicolumn{2}{|c|}{ Pigs } & \multicolumn{2}{|c|}{ Sheep } \\
\hline & 2009 & 2017 & 2009 & 2017 & 2009 & 2017 \\
\hline & \multicolumn{6}{|c|}{ Number and percentage } \\
\hline Tuberculosis & $3(0.0001)$ & $18(0.0009)$ & $300(0.001)$ & $208(0.0009)$ & $0(0.000)$ & $1(0.002)$ \\
\hline Erysipelas & - & - & $1480(0.008)$ & $2162(0.009)$ & - & - \\
\hline $\begin{array}{l}\text { Actinomycosis and } \\
\text { sepsis }\end{array}$ & $1262(0.07)$ & $1447(0.07)$ & $574(0.003)$ & $6820(0.03)$ & $1(0.004)$ & $9(0.02)$ \\
\hline $\begin{array}{l}\text { Emaciation } \\
\text { and watery muscles }\end{array}$ & $356(0.02)$ & $331(0.02)$ & $12(0.0001)$ & $1928(0.009)$ & $2(0.008)$ & $7(0.02)$ \\
\hline Icterus & $144(0.009)$ & $128(0.006)$ & $491(0.002)$ & $1158(0.005)$ & $0(0.000)$ & $9(0.02)$ \\
\hline $\begin{array}{l}\text { Organoleptic changes } \\
\text { Incomplete loss of }\end{array}$ & $553(0.03)$ & $805(0.04)$ & $7126(0.04)$ & $2070(0.009)$ & $5(0.02)$ & $1(0.002)$ \\
\hline $\begin{array}{l}\text { blood, natural death, } \\
\text { the slaugthering in } \\
\text { agony }\end{array}$ & $1161(0.07)$ & $421(0.02)$ & $3466(0.019)$ & $1685(0.007)$ & $2(0.08)$ & $23(0.05)$ \\
\hline $\begin{array}{l}\text { Foci of pus, } \\
\text { contaminations } \\
\text { and congestions }\end{array}$ & $128973(8.08)$ & $203239(10.20)$ & 5711400 (32.07) & 6264107 (28.07) & $3103(13.15)$ & $237(2.86)$ \\
\hline Cysticercosis & $908(0.05)$ & $779(0.04)$ & $145(0.0008)$ & 21 & $0(0.000)$ & $0(0.000)$ \\
\hline Echi & $46(0.002)$ & & $0(0.000)$ & 34904 & 768 (7.49) & $154(0.36)$ \\
\hline Fascic & $152173(9.54)$ & $171644(8.62)$ & - & - & 3269 (13.85) & $1117(2.58)$ \\
\hline Trich & - & - & $14(<0.0$ & ) & $0(0.000)$ & $0(0.000)$ \\
\hline Othe & $1128(0$. & $389(C)-1)$ & 4531 & 4751 & $180(0.76)$ & $0(0.000)$ \\
\hline Other $\mathrm{c}$ & 25440 (1.59) & 32685 (1.64) & $553602(3.10)$ & 1121866 ( & $246(1.04)$ & 644 (1.49) \\
\hline Total & 312147 (19.57) & $411886(20.68)$ & $6731752(37.81)$ & 7912069 (35.45) & $8576(36.35)$ & $3202(7.40)$ \\
\hline
\end{tabular}

$(-)-$ absent.

In ruminants, a high percentage of lesions was caused by the presence of parasites - liver fluke in cattle $(8.62 \%)$, sheep $(2.58 \%)$ and echinococcosis in sheep $(0.36 \%)$. High percentage of lesions was also caused by the presence of other parasites. This applies especially to pigs in which parasites were found in more than $2.5 \%$ of the examined carcasses. For comparison, the prevalence of liver fluke in cattle in Switzerland in 2003 was around 10\% (Rapsch et al. 2006), which is the current prevalence in Poland. Liver fluke is often a serious, chronic, general disease of the organism, and its symptoms in sheep include emaciation leading to cachexia (Fiss et al. 2013).

Other pathological changes occurred at a much lower rate. Tuberculous or tuberculous-like changes occurred in $0.0009 \%$ of the examined cattle, in $0.0009 \%$ of the examined pigs and $0.002 \%$ of the examined sheep, emaciation or watery muscles in 0.02 of cattle, $0.009 \%$ of pigs and $0.02 \%$ of sheep, incomplete blood loss, natural death or slaughter in agony occurred in $0.02 \%$ of cattle, $0.007 \%$ of pigs and $0.05 \%$ of sheep, and other changes in $1.64 \%$ of cattle, $5.03 \%$ of pigs and $1.49 \%$ of sheep. A very small number of trichinosis cases in pig meat can be considered satisfactory. In 2017 , only 5 cases of trichinosis were found in the entire country.

Comparing the frequency of symptoms and lesions with the data from 2009, it can be concluded that there was an increase in the percentage of animals diagnosed with tuberculosis in cattle (from $0.0001 \%$ to $0.0009 \%$ ) and a slight decrease in the percentage of animals diagnosed with tuberculosis in pigs (from $0.001 \%$ to $0.0009 \%$ ). The percentage of pigs with 
symptoms of erysipelas increased (from $0.008 \%$ to $0.009 \%$ ). The number of cysticercosis cases was reduced in cattle (from $0.05 \%$ to $0.04 \%$ ) and pigs (from $0.0008 \%$ to less than $0.00001 \%$ ), in addition to the decrease in the extensiveness of liver fluke in sheep (from $13.85 \%$ to $2.58 \%$ ) and in cattle (from $9.54 \%$ to $8.62 \%$ ). In the "other parasites" position, there was a decrease in the percentage of cattle, pigs and sheep. The percentage of pigs and sheep with symptoms registered as foci of pus, contamination and congestion decreased (from $32.07 \%$ to $28.07 \%$ and from $13.50 \%$ to $2.86 \%$, respectively). In terms of cattle, an increase in the proportion of animals with symptoms recorded as foci of pus, contamination and congestion was observed (from $8.08 \%$ to $10.20 \%$ ). In the "other changes" position, there was a slight increase in the proportion of cattle, pigs and sheep (Table 2).

The frequency of disease conditions and changes of slaughter animals in Poland varies depending on the territory. The data enabling the analysis of the occurrence of the most important conditions and changes in the disease of slaughter animals in specific regions of Poland are presented in Tables 3-6.

Table 3. The incidence of pus foci, contamination and congestions by voivodeships in 2017

\begin{tabular}{lrrrrrr}
\hline \multirow{2}{*}{ Voivodeship } & \multicolumn{2}{c}{ Cattle } & \multicolumn{2}{c}{ Pigs } & \multicolumn{2}{c}{ Sheep } \\
\cline { 2 - 7 } & number & \multicolumn{1}{c}{$\%$} & number & $\%$ & number & $\%$ \\
\hline Dolnośląskie & 4781 & 5.93 & 7356 & 26.04 & 0 & 0.00 \\
Kujawsko-Pomorskie & 859 & 27.44 & 285689 & 53.76 & 0 & 0.00 \\
Lubelskie & 19297 & 10.68 & 103862 & 11.77 & 0 & 0.00 \\
Lubuskie & 9 & 6.16 & 142802 & 97.05 & 0 & 0.00 \\
Łódzkie & 7736 & 3.42 & 1543724 & 29.22 & 0 & 0.00 \\
Małopolskie & 33928 & 10.82 & 264578 & 33.31 & 162 & 1.90 \\
Mazowieckie & 38965 & 11.44 & 1044163 & 49.09 & 50 & 0.61 \\
Opolskie & 770 & 28.31 & 55798 & 36.73 & 0 & 0.00 \\
Podkarpackie & 8134 & 16.38 & 139871 & 21.42 & 20 & 0.13 \\
Podlaskie & 28186 & 15.35 & 295887 & 31.20 & 3460 & 17.36 \\
Pomorskie & 588 & 1.56 & 991005 & 53.78 & 0 & 0.00 \\
Ślasskie & 7232 & 9.04 & 88665 & 21.17 & 61 & 4.72 \\
Świętokrzyskie & 699 & 5.64 & 34717 & 2.21 & 594 & 24.16 \\
Warmińsko-Mazurskie & 2545 & 18.14 & 195202 & 14.12 & 0 & 0.00 \\
Wielkopolskie & 46992 & 10.18 & 985557 & 24.30 & 4 & 0.42 \\
Zachodniopomorskie & 2518 & 51.18 & 85231 & 5.68 & 0 & 0.00 \\
\hline
\end{tabular}

The most common pathological changes in slaughter animals in Poland were foci of pus and congestion. Changes as such were found in cattle and pig carcasses in all voivodeships. The highest percentage of pus foci, congestion and contamination in cattle carcasses was found in the following voivodeships: Zachodniopomorskie $(51.18 \%)$, Opolskie $(28.31 \%)$ and Kujawsko-Pomorskie (27.44\%). The voivodeships with low frequency of such changes include the following voivodeships: Pomorskie, Łódzkie, Świętokrzyskie and Dolnośląskie Voivodeship (below 6\%). In pig carcasses, congestions and contamination occurred in all 16 voivodeships, much more frequently than in cattle carcasses. In the Lubuskie Voivodeship, such changes were found in over $97 \%$ of the examined carcasses, and in the Pomorskie and the Kujawsko-Pomorskie Voivodeship: in over $53 \%$ of the examined pig carcasses. Only in two voivodeships (Świętokrzyskie and Zachodniopomorskie) the frequency of pus foci, congestions and contamination in pig carcasses was lower than $10 \%$. Lesions in the form of pus foci, congestion and contamination were less frequent in sheep, but in the area of 9 voivodeships no such changes were observed at all. The largest number of the foregoing lesions was observed in the Świętokrzyskie (24.16\%) and Podlaskie (17.36\%) Voivodeships. 
Table 4 presents data showing the extent of liver fluke infestation in cattle and sheep in specific voivodeships.

Table 4. Extensiveness of liver fluke invasion in cattle and sheep by voivodeships in 2017

\begin{tabular}{lrrrr}
\hline \multirow{2}{*}{ Voivodeship } & \multicolumn{2}{c}{ Cattle } & \multicolumn{2}{c}{ Sheep } \\
\cline { 2 - 5 } & number & \multicolumn{1}{c}{ number } & $\%$ \\
\hline Dolnośląskie & 9652 & 11.96 & 0 & 0.00 \\
Kujawsko-Pomorskie & 5 & 0.16 & 0 & 0.00 \\
Lubelskie & 12618 & 6.98 & 0 & 0.00 \\
Lubuskie & 0 & 0.00 & 0 & 0.00 \\
tódzkie & 10743 & 4.75 & 0 & 0.00 \\
Małopolskie & 22836 & 7.28 & 306 & 3.59 \\
Mazowieckie & 44243 & 12.99 & 40 & 0.49 \\
Opolskie & 6 & 0.22 & 0 & 0.00 \\
Podkarpackie & 6075 & 12.23 & 710 & 4.69 \\
Podlaskie & 31227 & 17.00 & 0 & 0.00 \\
Pomorskie & 2524 & 6.71 & 0 & 0.00 \\
Śląskie & 2447 & 3.06 & 19 & 1.47 \\
Swiętokrzyskie & 192 & 1.55 & 15 & 0.61 \\
Warmińsko-Mazurskie & 1676 & 11.95 & 0 & 0.00 \\
Wielkopolskie & 27363 & 5.93 & 27 & 2.82 \\
Zachodniopomorskie & 37 & 0.75 & 0 & 0.00 \\
\hline
\end{tabular}

Liver fluke in cattle was not found only in the Lubuskie Voivodeship. Table 4 shows that the highest extensiveness of the liver fluke was found in the Podlaskie Voivodeship, where the fluke was found in $17 \%$ of the inspected cattle carcasses. The extensiveness of the liver fluke in sheep was much lower than in cattle. Liver fluke in sheep was found only in 6 out of 16 voivodeships, and in none of them the number of carcasses with changes indicating liver fluke did not exceed $5 \%$. The factor favoring the spread of the fluke in Poland is the increase in the population of deer, mainly European roe deer (Capreolus capreolus), which is an important host for Fasciola hepatica (Kornaś et al. 2005). Around $70 \%$ of the economic losses resulting from liver fluke disease result directly from pathological changes (Lis and Górski 2011a).

Table 5 presents data showing the extensiveness of echinococcosis in slaughter animals in particular voivodeships.

Table 5. Extensiveness of echinococcosis by voivodeships in 2017

\begin{tabular}{|c|c|c|c|c|c|c|}
\hline \multirow{2}{*}{ Voivodeship } & \multicolumn{2}{|c|}{ Cattle } & \multicolumn{2}{|c|}{ Pigs } & \multicolumn{2}{|c|}{ Sheep } \\
\hline & number & $\%$ & number & $\%$ & number & $\%$ \\
\hline Dolnośląskie & 0 & 0.000 & 28 & 0.100 & 0 & 0.00 \\
\hline Kujawsko-Pomorskie & 0 & 0.000 & 34 & 0.007 & 0 & 0.00 \\
\hline Lubelskie & 0 & 0.000 & 496 & 0.060 & 0 & 0.00 \\
\hline Lubuskie & 0 & 0.000 & 0 & 0.000 & 0 & 0.00 \\
\hline Łódzkie & 0 & 0.000 & 11469 & 0.220 & 0 & 0.00 \\
\hline Małopolskie & 0 & 0.000 & 54 & 0.007 & 0 & 0.00 \\
\hline Mazowieckie & 0 & 0.000 & 14773 & 0.700 & 0 & 0.00 \\
\hline Opolskie & 0 & 0.000 & 0 & 0.000 & 0 & 0.00 \\
\hline Podkarpackie & 0 & 0.000 & 7 & 0.001 & 154 & 0.10 \\
\hline Podlaskie & 0 & 0.000 & 3645 & 0.390 & 0 & 0.00 \\
\hline Pomorskie & 0 & 0.000 & 968 & 0.053 & 0 & 0.00 \\
\hline Śląskie & 0 & 0.000 & 1 & 0.001 & 0 & 0.00 \\
\hline Świętokrzyskie & 0 & 0.000 & 70 & 0.005 & 0 & 0.00 \\
\hline Warmińsko-Mazurskie & 0 & 0.000 & 147 & 0.010 & 0 & 0.00 \\
\hline Wielkopolskie & 0 & 0.000 & 574 & 0.020 & 0 & 0.00 \\
\hline Zachodniopomorskie & 0 & 0.000 & 2638 & 0.180 & 0 & 0.00 \\
\hline
\end{tabular}


In 2017, no echinococcosis was found in cattle, and in terms of sheep, echinococcosis was found only in 154 subjects $(0.10 \%)$ in the Podkarpackie Voivodeship. Echinococcosis of pigs was found in 14 voivodeships, but in general it occurred at a low frequency. The highest percentage of pig carcasses with echinococcosis symptoms was found in Mazowieckie, Podlaskie and Łódzkie Voivodeships $(0.22-0.70 \%$ of the inspected carcasses). In the Mazowieckie and Łódzkie Voivodeships, a total of 26202 cases of swine echinococcosis were found, which constituted about $75 \%$ of all pig echinococcosis cases found in Poland in 2017. This indicates the concentration of porcine echinococcosis in central Poland.

In $2017,0.12 \%$ of all examined carcasses were declared unfit for consumption. This constituted nearly 30 thousand carcasses in the entire country, with the largest number of carcasses unfit for consumption (over 25 thousand) being pork carcasses (Table 1). Table 6 shows the number and percentage structure of animal carcasses unfit for consumption, including specific voivodeships.

Table 6. Percentage of carcasses considered unfit for consumption by voivodeships in 2017

\begin{tabular}{lrrrrrr}
\hline \multirow{2}{*}{ Voivodeship } & \multicolumn{2}{c}{ Cattle } & \multicolumn{2}{c}{ Pigs } & \multicolumn{2}{c}{ Sheep } \\
\cline { 2 - 7 } & number & $\%$ & number & $\%$ & number & $\%$ \\
\hline Dolnośląskie & 322 & 0.40 & 0 & 0.00 & 0 & 0.00 \\
Kujawsko-Pomorskie & 29 & 0.93 & 209 & 0.04 & 0 & 0.00 \\
Lubelskie & 127 & 0.07 & 2571 & 0.29 & 0 & 0.00 \\
Lubuskie & 0 & 0.00 & 609 & 0.41 & 0 & 0.00 \\
Łódzkie & 654 & 0.29 & 1945 & 0.04 & 0 & 0.00 \\
Małopolskie & 645 & 0.21 & 151 & 0.02 & 7 & 0.08 \\
Mazowieckie & 1127 & 0.33 & 1289 & 0.06 & 0 & 0.00 \\
Opolskie & 4 & 0.15 & 40 & 0.03 & 0 & 0.00 \\
Podkarpackie & 107 & 0.22 & 352 & 0.05 & 24 & 0.16 \\
Podlaskie & 168 & 0.09 & 1261 & 0.13 & 18 & 0.90 \\
Pomorskie & 55 & 0.15 & 3340 & 0.18 & 0 & 0.00 \\
Śląskie & 76 & 0.10 & 23 & 0.006 & 1 & 0.08 \\
Świętokrzyskie & 15 & 0.12 & 2591 & 0.17 & 6 & 0.24 \\
Warmińsko-Mazurskie & 45 & 0.32 & 2932 & 0.21 & 0 & 0.00 \\
Wielkopolskie & 970 & 0.21 & 2621 & 0.06 & 0 & 0.00 \\
Zachodniopomorskie & 169 & 3.43 & 5265 & 0.35 & 0 & 0.00 \\
\hline
\end{tabular}

This data shows that the criterion of the number of pig carcasses declared unfit for consumption is dominated by voivodeships in the northern part of Poland. In the Zachodniopomorskie, Pomorskie and Warmińsko-Mazurskie Voivodeships, the number of such carcasses ranged from over 2,900 in the Warmińsko-Mazurskie Voivodeship to nearly 5,300 in the Zachodniopomorskie Voivodeship. Numerous pig carcasses were also declared unfit for consumption in the following voivodeships of central Poland: Wielkopolskie (over 2.6 thousand), Świętokrzyskie (nearly 2.6 thousand) and Lubelskie (over 2.5 thousand). The number of bovine carcasses considered unfit for consumption was over five times lower than that of pork, and the largest number of such carcasses was in the voivodeships of central Poland, i.e. Mazowieckie, Wielkopolskie and Łódzkie. The total number of bovine carcasses declared unfit for consumption in these three voivodeships amounted to 2751 , which constituted over $60 \%$ of all bovine carcasses disqualified as unfit for consumption in 2017 in Poland. The disqualification of sheep carcasses as unfit for consumption in Poland was limited to 56 carcasses only (Table 1), including 24 carcasses from the Podkarpackie Voivodeship and 18 sheep carcasses from the Podlaskie Voivodeship (Table 6). 


\section{CONCLUSIONS}

To summarize, the number of slaughter animals demonstrating health-related problems or disease symptoms and lesions in Poland is at a high level and even slightly increasing in case of cattle. A large number of contaminations and congestions indicates low care for the conditions of ante-mortem slaughter animals trading, as well as hygiene and conditions of slaughter, cutting and processing of carcasses. Quality deviations in the form of emaciation, watery muscles or insufficient blood loss of slaughtered animals indicate mistakes made during breeding or transport of animals for slaughter. Having considered that, legitimate concerns about the appropriate level of animal welfare can be raised. Parasitic diseases, particularly liver fluke in cattle and sheep, and echinococcosis in pigs in certain areas require more effective measures to reduce them. However, a very small number of trichinosis cases in pig meat can be considered as satisfactory.

\section{REFERENCES}

Butler W. R. 2000. Nutritional interaction with reproductive performance in dairy cattle. Anim. Reprod. Sci. 60, 449-457.

Drożdż J. 2018. Sytuacja ekonomiczno-finansowa producentów mięsa i jego przetworów w 2017 roku [Economic and financial situation of meat producers and its products in 2017]. Gospod. Mięs. 6, 28-29. [in Polish]

Fiss L., Adrien M.L., Marcolongo-Pereira C., Assis-Brasil N.D., Sallis E.S.V., Riet-Correa F., Ruas J.L., Schild A.L. 2013. Subacute and acute fasciolosis in sheep in southern Brazil. Parasitol. Res. 112(2), 883-887.

Januškevičienė G., Paulauskas V., Dailidavičienė J., Juozaitienė V. 2010. Analysis of pathologic lesions in the livestock and poultry slaughtered in the meat establishments of Lithuania. Vet. Zootech-Lith. 52(74), 33-42.

Kondracki M., Bednarek D., Cąkała S. 1996. Problemy chorób niezakaźnych w hodowli bydła [Problems of non-infectious diseases in breeding of cattle]. Med. Weter. 52 (6), 350-354. [in Polish]

Kornaś S., Nowosad B., Skalska M., Wróbel A. 2005. Zarażenie bydła mlecznego Fasciola hepatica w gospodarstwach drobnotowarowych [Dairy cattle infection with Fasciola hepatica in small farms]. Med. Weter. 61, 1368-1369. [in Polish]

Kozák A., Večerek V., Steinhauserová l., Chloupek P., Pištekova V. 2002. Results of slaughterhouse carcass classification (capable for human consumption, capable for processing and condemned) in selected species of food animals. Vet. Med.-Czech. 47(1), 26-31.

Libelt K. 2001. Występowanie odchyleń jakościowych u drobiu rzeźnego w Polsce w latach 1996-1999 [Qualitative changes in poultry slaughtered in Poland between 1996-1999]. Med. Weter. 57(2), 102-104. [in Polish]

Lis H., Górski K. 2011a. Motylica wątrobowa u bydła rzeźnego w Polsce w 2009 r. [Fasciola hepatica in slaughter cattle in Poland in 2009]. Życie Wet. 86(3), 224-225. [in Polish]

Lis H., Górski K. 2011b. Ocena wyników badania sanitarno-weterynaryjnego bydła rzeźnego w Polsce w 2009 r. [Evaluation the results of the sanitary and veterinary inspection of slaughter cattle in Poland in 2009]. Życie Wet. 86(4), 314-316. [in Polish]

Lis H., Górski K. 2012. Wyniki badania sanitarno-weterynaryjnego owiec rzeźnych w Polsce [The evaluation of sanitary and veterinary inspection results of slaughter sheep in Poland]. Życie Wet. 87(5), 419. [in Polish] 
Lis H., Górski K. 2017a. Ocena wyników badania sanitarno-weterynaryjnego bydła rzeźnego w Polsce w 2016 r. [Evaluation the results of the sanitary and veterinary inspection of slaughter cattle in Poland in 2016]. Życie Wet. 92(11), 831-833. [in Polish]

Lis H., Górski K. 2017b. Ocena wyników badania sanitarno-weterynaryjnego świń rzeźnych w Polsce w $2016 \mathrm{r}$. [The evaluation of sanitary and veterinary inspection results of the slaughter pigs in Poland in 2016]. Życie Wet. 92(12), 902-904. [in Polish]

Lis H., Iwanina M. 2011. Ocena wyników badania sanitarno-weterynaryjnego świń rzeźnych w Polsce w 2009 r. [The evaluation of sanitary and veterinary inspection results of the slaughter pigs in Poland in 2009]. Życie Wet. 86(2), 153-155.[in Polish]

Nielsen A. 2011. Data warehouse for assessing animal health, welfare, risk management and communication. Acta Vet.Scand. 53 (suppl. 1), 53.

Niżnikowski R., Rokicki T., Łaba S., Krajewski K. 2017. Sytuacja strategiczna sektora owczarskiego w Polsce - uwarunkowania hodowlane, rynkowe i ekonomiczne [Strategic situation of the sheep-farming sector in Poland - breeding, market and economic conditions]. Prz. Hod. 4, 1-6. [in Polish]

Radkowski M., Siemionek J., Zdrodowska B. 2010. Neoplastic lesions in slaughter animals in Warmińsko-Mazurskie voivodship (Poland) area during the years 2001-2007. Pol. J. Vet. Sci. 13(4), 669-672.

Rapsch C., Schweizer G., Grimm F., Kohler L., Bauer C., Deplazes P., Braun U., Torgerson P.R. 2006. Estimating the true prevalence of Fasciola hepatica in cattle slaughtered in Switzerland in the absence of an absolute diagnostic test. Int. J. Parasitol. 36, 1153-1158.

RRW-6. Sprawozdania z wyników urzędowego badania zwierząt rzeźnych i mięsa za 2009 i 2017 rok. 2017. Warszawa, Główny Inspektorat Weterynarii. [in Polish]

Sánchez P., Pallarés F.J., Gómez M.A., Bernabé A., Gómez S., Seva J. 2018. Importance of the knowledge of pathological processes for risk-based inspection in pig slaughterhouses (Study of 2002 to 2016). Asian Austral. J. Anim. Sci. 31(11), 1818-1827.

Świetlik K. 2019. Konsumpcja mięsa w Polsce w ostatnich latach [Consumption of meat in Poland in recent years]. Gospod. Mięs. 3, 32-44. [in Polish]

Szkucik K., Bełkot Z., Gondek M. 2012. Występowanie zmian chorobowych i odchyleń jakościowych w tuszach zwierząt łownych w Polsce w latach 2000-2011 [Occurrence of lesions and qualitative changes in game carcasses in Poland in 2000-2011]. Med. Weter. 68 (12), 755-761. [in Polish]

Szkucik K., Pyz-ŁukasikR., Paszkiewicz W. 2014. Występowanie zmian chorobowych i odchyleń jakościowych w tuszach owiec i kóz rzeźnych w Polsce w latach 2003-2013 [Prevalence of pathological lesions and quality changes in carcasses of slaughter sheep and goats in Poland in 2003-2013]. Med. Weter. 70(10), 626-629. [in Polish]

Vecerek V., Malena M., Malena Jr M., Voslarova E., Chloupek P. 2006. The impact of the transport distance and season on losses of fattened pigs during transport to the slaughterhouse in the Czech Republic in the period from 1997 to 2004. Vet. Med.-Czech. 51(1), 21-28.

Wajda S., Burczyk E. 2017. Zasady postępowania z bydłem w czasie obrotu przedubojowego [Rules for dealing with cattle during ante-mortem trade]. Gospod. Mięs. 68, 12-14. [in Polish]

\section{ANALIZA I PORÓWNANIE FREKWENCJI ZMIAN I OBJAWÓW CHOROBOWYCH U ZWIERZĄT RZEŹNYCH W POLSCE W LATACH 2009 I 2017}

Streszczenie. Celem badań była analiza i porównanie frekwencji objawów i zmian chorobowych u zwierząt rzeźnych w Polsce w latach 2009 i 2017 oraz określenie przyczyn ich występowania. Analizie poddano wyniki urzędowego badania poubojowego bydła, świń i owiec, przeprowadzonego przez Inspekcję Weterynaryjną. W ocenie przyczyn zmian chorobowych i niezdatności do spożycia uwzględniono takie jednostki chorobowe, jak: gruźlica, promienica i posocznica, a także odchylenia jakościowe: wychudzenie i wodnicę, żółtaczkę, zmiany organoleptyczne, niedostateczne wykrwawienie, śmierć naturalną, ubój w agonii, ogniska ropne, zanieczyszczenia, przekrwienia 
i inne zmiany oraz inwazje pasożytnicze: wągry, bąblowce, motylicę wątrobową i włośnicę. Stwierdzono, że liczba zwierząt rzeźnych, wykazujących zaburzenia stanu zdrowia bądź objawy i zmiany chorobowe, utrzymuje się w Polsce na wysokim poziomie, a w przypadku bydła nawet nieznacznie wzrasta. Duża liczba zanieczyszczeń i przekrwień świadczy o małej dbałości o warunki obrotu przedubojowego zwierząt rzeźnych, a także o higienę i warunki uboju oraz rozbioru i obróbki tusz. Odchylenia jakościowe w postaci wychudzenia, wodnicy lub niedostatecznego wykrwawienia ubijanych zwierząt wskazują na błędy popełniane w czasie chowu bądź podczas transportu zwierząt rzeźnych. W związku z tym można mieć uzasadnione obawy dotyczące dobrostanu zwierząt. Choroby pasożytnicze, szczególnie motylica wątrobowa u bydła i owiec oraz bąblowica u świń, w niektórych rejonach wymagają bardziej skutecznych działań w celu ich ograniczenia. Za zadowalającą natomiast można uznać bardzo małą liczbę przypadków włośnicy w mięsie świń.

Słowa kluczowe: zwierzęta rzeźne, badanie poubojowe, zmiany chorobowe. 